\title{
Mentoring and Supervising International Students in School Counseling Programs
}

\author{
Bridget Asempapa \\ West Chester University of Pennsylvania, USA
}

\begin{abstract}
Graduate counseling programs in the United States have increased their population of international students. However, limited studies have addressed the challenges of international students, specifically in school counseling programs. Considering the cultural disparities that exist for international school counseling students and the challenges associated with being an international student in general, this article identifies and delineates a culturally appropriate mentoring and supervision model that has the potential to shape the experiences of international students in school counseling training programs. The model presented through a case study argues that intentional mentoring and supervision for international school counseling students enhance productivity during students' field experiences in U.S. school systems.
\end{abstract}

Keywords: counselor education, culturally appropriate mentoring, graduate international students, school counseling, supervision

Data reported over the years have indicated that U.S. colleges and universities have consistently observed an increase in enrollment of international students. As evidenced in the 2017 Open Doors report, data recorded showed a total enrollment of 623,805 international students for the 2007-2008 academic year as compared with $1,078,822$ international students' total enrollment in the 2016-2017 academic year. The same report indicated that international students constituted about $5.3 \%$ of the total U.S. enrollment (Institute of International Education, 2018). With this type of growth, international students' needs have become relevant to various academic institutions and fields, including counselor education programs, which has resulted in increased research studies that focus on this population (Hegarty, 2014; Leong, 2015; $\mathrm{Ng}, 2006)$. 
The interest in international students' growth prompted $\mathrm{Ng}$ (2006) to investigate the number of students enrolled in U.S. counselor education programs accredited by the Council for Accreditation of Counseling and Related Educational Programs (CACREP). Findings indicated that 73 out of 96 accredited programs that participated in the study reported enrollment of international students during the spring semester of 2004. A recent report from CACREP (2016) showed that of 1,741 doctoral students enrolled in CACREP accredited counseling programs, $4.14 \%$ were international students. The same report indicated that international students constituted about $1 \%$ of master's students in CACREP accredited counseling programs. These studies did not report data on counseling specializations. Nevertheless, studies from related fields such as marriage and family therapy (Mittal \& Wieling, 2006) and rehabilitation counseling programs (Zhu \& Degeneffe, 2011) have investigated the challenges of international students. Additionally, Behl, Laux, Roseman, Tiamiyu, and Spann (2017) have examined the acculturative needs of international students in CACREP programs. A consistent theme in these studies points to the essence of personal, academic, social, and cultural support for international students in counseling programs.

Unfortunately, there is a dearth of literature that speaks more directly about supportive measures that foster international school counseling students' training in U.S. school counseling programs. International school counseling students, in this context, imply international graduate students enrolled in master's level school counseling programs. Therefore, the purpose of this article is to: (a) address the gap in the literature concerning the challenges international students often face in school counseling programs; (b) explore culturally sensitive mentoring and supervision alternatives required for promoting international school counseling students' learning; and (c) create an awareness of the individual and global benefits of such measures for all stakeholders.

As school counseling gains credence worldwide, international students are coming to the US in search of graduate training in this area of counseling. The presence of international school counseling students adds multicultural value not only to counseling programs but also to U.S. PreK-12 school systems. The interactions that occur between international school counseling students and their domestic counterparts create multicultural awareness (Behl et al., 2017). Additionally, the presence of international students in counseling programs provide experiences and continued opportunities for increased internationalization (Leong, 2015) among domestic students, faculty members, and the site supervisors. Moreover, there is economic benefit for U.S. colleges and universities because of the tuition disparities between international and domestic students (Hegarty, 2014).

\section{LITERATURE REVIEW}

\section{Needs of International Counseling Students}

A plethora of studies have supported the assertion that international students generally experience social, personal, cultural, and academic challenges that may hinder their success when studying in the US (e.g., Boafo-Arthur, 2014; Burlew \& 
Alleyne, 2010; Mittal \& Wieling, 2006; Olivas \& Li, 2006). Specific to professional counseling, Tidwell and Hanassab (2007) administered a 50-item self-report questionnaire to 640 international counseling students (ICSs) from public universities in the west coast of the United States to investigate their needs and experiences. Results from the study indicated that the highest needs pertained to issues regarding immigration, academic information, and career development challenges. When asked about their personal changes in awareness, the participants reported that the greatest change was related to philosophical and cultural awareness. Moreover, ICSs have also reported challenges with language proficiency, discrimination, and acculturation related to theory, practice, and supervision in an environment other than their native countries (Mittal \& Wieling, 2006; Ng \& Smith 2009; Nilsson, 2007). Nilsson's (2007) study provided a synopsis of the impacts of understanding both culture and language proficiency on the client-counselor and the supervisor-supervisee relationship as described in the following: (a) cultural understanding being paramount to empathy; (b) language proficiency being vital to communication; (c) acculturation influencing self-efficacy in ICSs as well as affecting the working alliance between supervisor and supervisee; and (d) correlation between ICSs' well-being and productivity versus understanding of culture and proficiency in language.

Counselor education programs are likely to do a disservice to their ICSs if instructions and curriculum are presented without consideration to cultural disparities. Ng and Smith (2009) compared the experiences of domestic students and ICSs, and highlighted some of the pertinent differences that exist in these groups. The results from the study indicated that compared to domestic students, ICSs have:

higher levels of academic problems, English proficiency issues, cultural adjustment problems, social/relational problems with peers, difficulties in clinical courses, problems fitting in at clinical sites, problems communicating with clients due to language barriers, conflicts with Western understandings, approaches to treating mental health, discrimination by faculty members, and discrimination by fellow American trainees (p. 66).

While these problems may be true of many international students, $\mathrm{Ng}$ and Smith (2009) cautioned the generalization of these results. Nevertheless, most universities have established protocols by which they monitor and attempt to resolve some of these issues. For instance, most universities assess English language proficiency to ensure that international students (Education USA, 2018), including ICSs, who are not proficient in English language enroll in English language classes to enhance their proficiency. In recognizing the potential disorientation and acculturative difficulties, some institutions have specific measures, such as mentoring programs (Yip, 2014), to help international students adjust to the U.S culture. Despite these general challenges and supportive measures, international school counseling students (ISCSs) are likely to face important and specific school counseling related issues that are missing in the literature. 


\section{Challenges ISCSs Face in U.S. School Counseling Training Programs}

A review of the literature surprisingly revealed little to no studies on exploring international school counseling students' (ISCSs) development and experiences. None of the previous studies (Behl et al., 2017; Ng \& Smith, 2009) about ICSs focused on ISCS. Ng and Smith's (2009) work mentioned the inclusion of four school counseling students in the sample for their study. However, there was no specific analysis in relation to the students' program of study when compared to other programs. The next paragraphs provide a summary of the expectations for a master's degree in school counseling, and the specific challenges ISCSs might face in U.S. school counseling training programs.

School counseling programs accredited by CACREP (2015) are guided by standards to develop curricula that offer eight common core courses, contextual and elective courses, and placement in PreK-12 school settings for field experience. Although the minimum requirement for a school counseling program is expected to be 60 credit hours by July 1, 2020, currently the expected minimum is 48 credit hours. Included in most school counseling curricula are the American School Counselor Association (ASCA) standards and national models (ASCA, 2012, 2016) that serve as foundation and framework for practice. Students engage in 100 clock hours of practicum and 600 clock hours of internship. During that period of field experience (practicum and internship), onsite and faculty supervisors provide a minimum of 1$\mathrm{hr}$ and $1.5 \mathrm{hr}$ per week supervision respectively for students. These requirements are uniform for both domestic students and ISCS.

Anecdotal experiences show that most students are able to complete these requirements in two-years, with the first year serving as preparation for field experience. By the second year, most full-time students are beginning field experience. However, unlike the domestic students, ISCS have no experience with the American school systems, and do not understand the operations in PreK-12 schools. Although it could be argued that out-of-state domestic students experience some level of unfamiliarity, it does not compare to the experiences of ISCSs. The first year for ISCSs is often used to gain familiarity with the American culture, teaching, and learning style. This is evidenced by reports of international students' adjustment struggles with acculturation (Hanassab \& Tidewell, 2002; Hirai, Frazier, \& Syed, 2015; McDowell, Fang, Kosutic, \& Griggs, 2012). To further complicate issues, most of the ISCSs (like their domestic colleagues) have the responsibility of finding school sites for field experience. Again, this generates stress for ISCSs as they compete for school placement sites with their domestic colleagues who sometimes have prior network connections in the schools. When it comes to field placement, an issue that is of great importance is proximity. If an ISCS does not possess a driver's license during the field placement, lack of mobility becomes an added challenge.

Some may argue that ISCSs are not required to complete the program within 2 years, especially with some counseling programs transitioning from 48 to 60 credit hours. Nonetheless, given that most ISCSs are paying fees out of pocket or are on scholarships (Gautz, 2017; Schulte \& Choudaha, 2014) they are not afforded the luxury of pacing themselves in their academic pursuit. According to the United States Citizenship and Immigration Services (USCIS, 2018) regulations for international 
students, ISCSs are required to maintain full-time student status to retain their legal status in the US. Moreover, when the scholarships offered to students are time restricted (usually within 2 years), it creates further financial burden if ISCSs prolong the duration of their study. In addition, scholarships sometimes do not cover summer classes, and international students' tuition fees are higher in comparison to the domestic students' tuition fees (Hegarty, 2014). Moreover, international students are often limited in finding job opportunities because employability is often restricted to university campuses (Behl et al., 2017), making it increasingly difficult for ISCSs to have financial freedom that could allow a comfortable pacing of their training.

Considering the political, economic, and social-systemic influences on the operation of PreK-12 schools in the US (Lunenburg, 2010), one of the biggest challenges ISCSs face with field experience is acculturative stress. Acculturation to the U.S. culture has proven to be a significant source of stress for most international students. Adjustment (McDowell et al., 2012), psychological and sociocultural (Hirai, et al., 2015), and academic challenges (Hanassab \& Tidewell, 2002) are among some of the documented acculturative stresses. International counseling students are not exempt from these identified acculturative stresses (Behl et al., 2017). However, because PreK-12 schools are operated as social systems that have defined population, goals, and expected interaction with the external environment (Norlin, 2009), it can be stressful for ISCSs to navigate the various elements, including access to resources, transformation processes, outputs, and feedback received from the external community (Lunenburg, 2010).

ISCSs are obligated to understand the internal operations that affect the success of all stakeholders within the school system. They need to acquire knowledge about the cultural dynamics in the school system, and understand how the various professional standards (not just ASCA standards and models but the current teaching standards - e.g., Common Core) apply to the work they do with all stakeholders in their assigned schools during their field experience. ISCSs have a responsibility to provide counseling to U.S. school children at their field placement during practicum and internship experiences, and are expected to collaborate with school stakeholders whose culture they may not fully understand. Cultural competence requires understanding and receptivity, which Nilsson (2007) has explained requires “...knowledge about traditions, beliefs, values, and non-verbal norms, [and] is fundamental to being able to empathize with clients' feelings and experiences" ( $p$. 36). Inherently, international students need time, exposure, and experience to understand the American culture and school system.

\section{SUPERVISION AND MENTORING: WHY IT MATTERS TO ISCS}

A critical component that is generally considered mandatory and paramount to the development of all students - domestic and ISCS - is supervision (ASCA, 2016; CACREP, 2015). Bernard and Goodyear (1998) defined supervision as a professional relationship between a more senior member of a profession to a more junior member of the same profession, with the purpose of enhancing professional competence, evaluation, and gatekeeping. In other words, the supervisor/supervisee relationship is a formal interaction that ensures that the ISCS is appropriately monitored to guarantee 
no harm to their potential clients. When ISCSs begin field experience, supervision also serves as an avenue to fill in the missing gaps; thus this is the period where they apply the knowledge and harness skills gained in the classroom. However, given its hierarchical and evaluative nature (Bernard \& Goodyear, 2014), supervision in isolation is insufficient to bridge the gap related to acculturative stress in ISCSs.

On the other hand, mentoring serves as an appropriate supplement to supervision. Mentoring can be a formal or informal relationship where an experienced wellregarded individual provides guidance to another individual who seeks to develop on a personal or professional level (Mellen \& Murdoch-Eaton, 2015). In instances where mentoring has been used and valued, peer mentors (Lee, 2017) or a more experienced person have mentored the less experienced person (Ku, Lahman, Yeh, \& Cheng, 2008). For instance, Yip (2014) described a mentoring program in Ohlone College, where faculty and staff were invited and encouraged to be mentors to international students in the college. Yip reported that on average, 20 to 25 mentors were involved in the program each semester to provide support, encouragement, and most importantly to help the international students adjust to a new environment. The experiences shared by mentors and mentees indicated a mutual benefit (personal and cultural development) for both parties.

In training ISCSs, mentoring seems appropriate, especially during the first-year curriculum because it is free of evaluation. Mentoring can be made an integral part of the ISCS curriculum to provide culturally sensitive transitions and understanding of PreK-12 school systems. Most importantly, the use of mentoring before supervision could be equated to some of Lev Vygotsky's discussion of sociocultural learning theory, specifically related to zone of proximal development (ZPD) and scaffolding (John-Steiner \& Mahn, 1996; Peer \& McClendon, 2002; Vygotsky, 1978). Vygotsky defined ZPD as the period in which an individual is capable of accomplishing a task independently versus doing so with support. Within the ZPD is a critical component of scaffolding, the act of providing developmentally appropriate support by a more capable individual. As part of the support, the social environment is made conducive for active learning and a gradual experience of independence to occur. With ISCSs being new to the U.S. education system and culture, it seems mentoring as part of the curriculum would offer the necessary scaffolding for them to adjust to the U.S. education system and culture. This may also help the ISCSs to develop self-efficacy as they gain confidence in their knowledge and abilities.

In the following sections, the author of this article describes two critical periods when mentoring can be offered to the ISCSs: (a) prior to field experience, and (b) as part of supervision during field experience. The author recommends that a more experienced professional (a school counselor) should provide mentoring to the ISCSs. Because consistency, continuity, and comfort are so critical to developing confidence and productivity, it is further recommended that ISCSs maintain the same mentor and site in both Part A (where ISCSs receive mentoring prior to field experience) and Part $\mathrm{B}$ (where ISCSs receive mentoring as part of supervision during the field experience phase). Both parties need to be in agreement of continuing the professional relationship. If for some reason, the mentor in Part A is unable or unwilling to serve as supervisor-mentor in Part B, it is recommended that the ISCS should be placed with a school counselor within the same school district. Following the discussion of 
this culturally sensitive mentoring-supervision model is a simulated case presented to illustrate how mentoring before and during supervision becomes helpful to ISCSs.

\section{PROPOSED CULTURALLY SENSITIVE MENTORING AND SUPERVISION MODEL FOR ISCS}

\section{Part A: Mentoring Prior to Field Experience}

For the purposes of mitigating acculturative stress, it is proposed that ISCSs should be paired with practicing school counselors who will serve as mentors at the onset of the ISCS school counseling education in the US. This initial mentoring prior to supervision creates the avenue for ISCSs to establish trusting relationships with knowledgeable and experienced school counselors who can serve in the role of a guide and a teacher. Reese (2006) described the mentor-mentee relationship as the former guiding the latter through the pathway of life. Unlike a faculty mentor, a practicing school counselor can guide the ISCS by providing developmentally appropriate exposure to the school system, and supplement the theoretical or conceptual knowledge gained in the classroom. In the spirit of exposing the ISCS to the U.S. PreK-12 school system, a peer mentor might not suffice because a peer mentor may not have easy access to the knowledge that comes from practice.

Ideally, faculty members in school counseling programs should take on the responsibility of contacting school counselors within close proximity to the university and enlisting interest from school counselors who can and are willing to help the ISCS understand and become familiar with the PreK-12 school system. It is essential that the selected school and the school counselor are in close proximity as most ISCSs may not have cars or the license to drive at the time of their enrollment. Additionally, the faculty members need to make the arrangements on behalf of the ISCS because the ISCS will not have access and may be unfamiliar with the local community. Faculty members can also collaborate with the international students' offices within their institutions to offer a workshop that adequately prepares the selected school counselor-mentors for their roles. Moreover, the ISCS should be given the courtesy of making the decision to engage in the mentoring process. In essence, the mentoring program should be an added resource which is highly encouraged, and not necessarily a mandate.

Once both the school counselor and the ISCS have made contact they could engage in activities including: (a) making arrangement about meeting schedules; (b) creating opportunities to know each other; (c) educating ISCSs about the U.S. culture and the PreK-12 school culture; (d) discussing the ISCS's goals and aspirations; (e) discussing roles and responsibilities; (f) finding commonalities in activities the mentor and mentee can explore; and (g) developing a plan for the mentoring activities. During this phase of their professional relationship, the mentor and mentee can foster multicultural competence in each other. But most importantly, the ISCS is provided a conducive environment to receive support, exposure, and encouragement. The next section (Part B), is a discussion of mentoring as part of supervision for the ISCS. It is worth mentioning that ISCS and supervisee are used interchangeably in Part B. 


\section{Part B: Mentoring as Part of Supervision during Field Experience}

Supervision is an essential component of the ISCS's development as a school counselor in training (CACREP, 2015). Consequently, a suitable proposed supervision model for this phase of ISCS development is the Discrimination Model Reconceptualized (DM-R; Pillay, Fulton, \& Robertson, 2015). The DM-R model integrates mentoring into supervision, and can be applied to the school counseling setting as a supportive measure for ISCSs during the field experience phase of the training. In the DM-R, Pillay and his colleagues adapted Anderson and Shannon's (1988) mentoring model and integrated it into the Discrimination Model of supervision (Bernard, 1979; Bernard \& Goodyear, 2014). The DM-R supervision model suggests that the onsite supervisor functions in six roles with three foci as a supervisor-mentor, namely: teacher, counselor, consultant, sponsor, encourager, and friend, with focus on conceptualization, intervention, and personalization to enhance growth for the supervisee. This creates a pairing of 6 Roles $\times 3$ Foci in the model.

During the conceptualization focus, the supervisor-mentor helps the supervisee to understand and process the underlying issues that the clients present during the counseling sessions. The supervisee is able to use that understanding to develop goals and interventions that meet the clients' needs. With intervention focus, the supervisormentor observes to ascertain how well the supervisee is applying the knowledge, skills, and attitudes to cases within the school setting. Issues related to the supervisee's personal style and limitations are addressed in personalization. Additionally, during the above-mentioned foci, the supervisor-mentor functions as a teacher; thus, teaching some interventions or skills that may be necessary within the school setting. As a counselor, the supervisor-mentor listens and provides appropriate feedback that enhances growth and wellness for the supervisee. In some situations, the supervisor-mentor may function as a consultant when the supervisee needs to analyze and process issues presented in sessions. In befriending, the supervisormentor will provide unconditional positive regard for the ISCS. It is important to note that the supervisor-mentor may need to use judgment in determining the extent of the "friendship." Ideally, the relationship should be built on mutual respect, ensuring appropriate boundaries. Preferably, the author of this paper suggests the use of an "ally" in place of a "friend." Thus, as an ally, the supervisor-mentor will still provide unconditional positive regard, but maintain a level of professional boundary. In the role of a sponsor, the supervisor-mentor will support, advocate, promote, and protect the supervisee. Finally, as an encourager, the supervisor-mentors will encourage selfefficacy and confidence through the empowering activities they engage in with ISCS.

Effective practice as suggested by Borders (2014) indicates that the supervisor has the responsibility at the onset of the field experience to sign a contract with the supervisee, outlining roles and responsibilities. The supervisor-mentor will engage in a discussion with the ISCS about the roles, responsibilities, and expectations for the duration of the field experience. In addition, the supervisor-mentor will engage in the following activities to make for a fluid transition from Part A to Part B of these culturally sensitive mentoring and supervision measures: (a) assessing the ISCS's comfort level with expectations at various stages of the field experience; (b) setting goals and aspirations with the ISCS; (c) providing support and constructive feedback; 
(d) teaching; (e) providing opportunities for growth and learning by allowing the ISCS to participate or lead some school counseling activities; (f) continuing discussions on cultural issues; ( $\mathrm{g}$ ) continuing to formulate working relationship; and (h) providing counsel and consultation. The following simulated case study is presented to show how the components of the DM-R can be applied to the case of Nihan in Part A and B.

\section{THE CASE OF NIHAN}

\section{Part A: Mentoring Prior to Field Experience}

Nihan, a 27-year-old Turkish student, is a first-year ISCS. She has a 2-year scholarship from her government for her studies. Criteria for the scholarship include conducting a thesis on a topic that relates to an issue predominant in schools in her home country. Using strategies learned from being in the U.S. PreK-12 school systems, she is required to make recommendations by developing a program that can help resolve some of the school counseling-related problems in Turkey upon her return home. Table 1 provides a description of six roles in the DM-R model to foster Nihan's and her mentor's interaction.

Table 1: Applying the Mentoring Roles of the Discrimination ModelReconceptualized Prior to the Field Experience Phase

\begin{tabular}{ll}
\hline Mentoring & How it applies to Nihan's situation \\
\hline Consulting & Nihan indicates that she would like to explore aspects of \\
school counseling she can use to inform her thesis. & Mentor assists Nihan in identifying issues in Turkish \\
& schools, and assists with exploring resources used in U.S. \\
& schools that can be applied to the thesis project. \\
& Nihan does not know how to begin. She needs input from \\
Teaching & Mentor could discuss the American School Counsel \\
& Association's three domains with Nihan: academic, career, \\
& and personal/social. \\
& Nihan identifies that she would like to work on gender \\
disparity issues, mainly focusing on empowering girls to \\
pursue higher education. However, she struggles with her \\
confidence in adequately addressing this issue. \\
Mentor assists Nihan in reflecting on the strengths she has, \\
and helps Nihan to gain insight in her role as an advocate. \\
Nihan realizes another school counselor within her mentor's \\
school district is running "an empowering girls program." \\
She is interested in connecting with that school counselor.
\end{tabular}




\begin{tabular}{ll}
\hline Mentoring & How it applies to Nihan's situation \\
\hline & $\begin{array}{l}\text { Mentor invites Nihan to school and offers to connect her } \\
\text { with that other school counselor. The mentor offers to } \\
\text { attend some of the events with Nihan. }\end{array}$ \\
Sponsoring & $\begin{array}{l}\text { Nihan would like to engage in an action research by } \\
\text { replicating the "empowering girls' project" at her mentor's } \\
\text { school. } \\
\end{array}$ \\
& $\begin{array}{l}\text { The mentor provides encouragement, and helps Nihan to } \\
\text { put together a proposal for the project. } \\
\text { Nihan and mentor meet during scheduled times as planned. } \\
\text { Throughout the year, the mentor checks in with Nihan and } \\
\text { provides encouragement for the development of the project. }\end{array}$ \\
\hline
\end{tabular}

\section{Part B: Mentoring as Part of Supervision during Field Experience}

Nihan has now started her practicum and internship. She has some understanding about how the school system works, and has appreciation for the dynamics within the school. She is currently seeing an 18 year old male high school senior who is not interested in college, but wants to explore other options for his career path. Nihan, reports that she does not know how to help this student. Her difficulty stems from her value for education, and also realizing the potential the student possesses. Table 2 shows a description of the application of the DM-R mentoring and supervision model in the case of Nihan.

Table 2: Applying Discrimination Model-Reconceptualized (Mentoring and Supervision) During the Field Experience Phase

\begin{tabular}{|c|c|c|c|}
\hline Teacher & Counselor & Consultant & Mentor \\
\hline \multicolumn{4}{|c|}{ Intervention } \\
\hline $\begin{array}{l}\text { Nihan wants to } \\
\text { assess the client's } \\
\text { interest but } \\
\text { struggles with the } \\
\text { use of Holland's } \\
\text { interest inventory. }\end{array}$ & $\begin{array}{l}\text { Nihan struggles } \\
\text { with challenging } \\
\text { the client's views } \\
\text { and discrepancies } \\
\text { associated with } \\
\text { college education. }\end{array}$ & $\begin{array}{l}\text { Nihan wants to } \\
\text { explore the use of } \\
\text { Adler's early } \\
\text { recollection to } \\
\text { gain insight from } \\
\text { the client. }\end{array}$ & $\begin{array}{l}\text { Nihan wants to } \\
\text { learn more about } \\
\text { career counseling. } \\
\text { Supervisor looks } \\
\text { for professional } \\
\text { development }\end{array}$ \\
\hline $\begin{array}{l}\text { Supervisor } \\
\text { discusses the use } \\
\text { of the interest } \\
\text { inventory and its } \\
\text { purpose. }\end{array}$ & $\begin{array}{l}\text { The supervisor } \\
\text { offers Nihan the } \\
\text { opportunity to say } \\
\text { what she would } \\
\text { wish to say to the } \\
\text { client. }\end{array}$ & $\begin{array}{l}\text { Supervisor } \\
\text { provides } \\
\text { resources about } \\
\text { the use of early } \\
\text { recollections. }\end{array}$ & $\begin{array}{l}\text { opportunities in } \\
\text { career counseling } \\
\text { to attend with } \\
\text { Nihan. } \\
\text { (Befriending } \\
\text { "Ally") }\end{array}$ \\
\hline
\end{tabular}




\begin{tabular}{|c|c|c|c|}
\hline Teacher & Counselor & Consultant & Mentor \\
\hline \multicolumn{4}{|c|}{ Conceptualization } \\
\hline $\begin{array}{l}\text { Nihan does not } \\
\text { explore other } \\
\text { factors that may } \\
\text { lead to client's } \\
\text { refusal to attend } \\
\text { college. }\end{array}$ & $\begin{array}{l}\text { Nihan assesses } \\
\text { the client as being } \\
\text { defiant and } \\
\text { disrespectful } \\
\text { because of his } \\
\text { assertiveness. }\end{array}$ & $\begin{array}{l}\text { Nihan suggests } \\
\text { that she would } \\
\text { like to discuss the } \\
\text { client's issues } \\
\text { with his parents. } \\
\text { Supervisor assists }\end{array}$ & $\begin{array}{l}\text { Nihan feels } \\
\text { incompetent in } \\
\text { dealing with some } \\
\text { of the issues that } \\
\text { the student } \\
\text { presents. }\end{array}$ \\
\hline $\begin{array}{l}\text { The supervisor } \\
\text { explains how } \\
\text { other factors, } \\
\text { such as home } \\
\text { conditions, could } \\
\text { inform the client's } \\
\text { decision. }\end{array}$ & $\begin{array}{l}\text { Supervisor } \\
\text { processes the } \\
\text { statements with } \\
\text { Nihan to help her } \\
\text { appreciate the } \\
\text { client's } \\
\text { assertiveness. }\end{array}$ & $\begin{array}{l}\text { Nihan in making } \\
\text { that decision } \\
\text { based on FERPA } \\
\text { regulations. }\end{array}$ & $\begin{array}{l}\text { The supervisor } \\
\text { provides support } \\
\text { by assuring Nihan } \\
\text { that cultural } \\
\text { differences take } \\
\text { time to get } \\
\text { adjusted to. } \\
\text { (Encouraging) }\end{array}$ \\
\hline \multicolumn{4}{|c|}{ Personalization } \\
\hline $\begin{array}{l}\text { Nihan's struggles } \\
\text { with being alone } \\
\text { with a male in a } \\
\text { room. } \\
\text { Supervisor } \\
\text { reviews video } \\
\text { with Nihan and } \\
\text { addresses how } \\
\text { that may interfere } \\
\text { with working } \\
\text { alliance. }\end{array}$ & $\begin{array}{l}\text { Nihan's difficulty } \\
\text { with the client } \\
\text { inhibits her } \\
\text { genuineness with } \\
\text { the client. } \\
\text { The supervisor } \\
\text { reflects her } \\
\text { feelings of } \\
\text { discomfort and } \\
\text { helps Nihan to } \\
\text { reflect on where } \\
\text { the discomfort } \\
\text { stems from. }\end{array}$ & $\begin{array}{l}\text { Nihan realizes her } \\
\text { collectivist values } \\
\text { are getting in the } \\
\text { way of respecting } \\
\text { client's } \\
\text { individualistic } \\
\text { values. } \\
\text { Supervisor helps } \\
\text { Nihan to process } \\
\text { the client's } \\
\text { culture. }\end{array}$ & $\begin{array}{l}\text { Supervisor wants } \\
\text { to help Nihan } \\
\text { reduce her } \\
\text { discomfort with } \\
\text { being in the same } \\
\text { room with males. } \\
\text { The supervisor } \\
\text { offers Nihan an } \\
\text { opportunity to } \\
\text { work with her and } \\
\text { other male staff } \\
\text { members on a } \\
\text { project. } \\
\text { (Sponsoring) }\end{array}$ \\
\hline
\end{tabular}

It is evident in the above simulated case that integrating mentoring in the ISCS curriculum can be a developmentally and culturally appropriate strategy to acclimate the ISCS. The two-phase mentoring added to supervision can be a suitable alternative to the existing curricula. As shown in the case of Nihan, the importance of mentoring provided by a school counselor to an international student at the pre-field experience phase cannot be overemphasized. Moreover, the case study showed the essence of mentoring and how the roles depicted in the DM-R are applicable to Nihan's situation. Part A showed the mentor's roles as Nihan was provided support for a critical component of the scholarship she received from the Turkish government. Through the interaction with her mentor, Nihan received supplemental teaching on the three ASCA domains, and their application to the task required for her 
scholarship. Nihan was exposed to practical strategies that she could explore during her field experience phase. This access to the school system and observation of its operations is free of evaluation and it is an essential element to building self-efficacy in ISCS.

In Part B, the full DM-R model was implemented to show the various struggles Nihan encountered, but with critical attention to Nihan's developmental needs, as well as her client's needs. As a Turkish ISCS, we see Nihan experience typical challenges that counselor trainees face at the initial phase of field placements including cultural differences, relationship formation with clients, and feeling incompetent (Park, Lee, \& Wood, 2017). When the typical struggles and acculturation challenges such as the clash of cultures conflated, we saw Nihan's internal struggles become pronounced. Nonetheless, the use of the DM-R model allowed the supervisor to provide developmentally appropriate supervision and mentoring to scaffold Nihan's professional growth.

\section{CONCLUSION AND IMPLICATIONS}

The purpose of this article was to bring attention to the expectations for a master's degree in school counseling, highlight the challenges that ISCSs often face in U.S. school counseling training programs, and suggest measures that can facilitate learning and enhance the transitions throughout various developmental stages for this population. Research indicates that international students generally encounter a disorientation because of exposure to new culture, teaching, and learning styles in the host country (Leong, 2015). However, this disorientation increases when ISCSs have an added stress that comes with engaging in apprenticeship in American school systems. Considering the DM-R model as being an appropriate mix of mentoring and supervision strategies, and the two-part simulated case study presented above, it represents a more culturally sensitive way to ensure proper scaffolding for ISCS in U.S. school counseling training programs.

Although supervision is a mandate from an accreditation perspective (CACREP, 2015), research is abundant showing supervision as a necessary supportive and accountability measure for counselor trainees (Borders, Brown, \& Purgason, 2015; Meany-Walen, Davis-Gage, \& Lindo, 2016; Ng \& Smith, 2012). Literature about ICSs and supervision also indicate that the supervisory working alliance actually promotes self-efficacy, and that it is likely to reduce role ambiguity in this population (Akkurt, Ng, \& Kolbert, 2018). However, the argument presented in this article suggests that, for ISCSs, supervision alone is insufficient. Mentoring, whether by site supervisor, faculty, or peers, can be incredibly helpful to international students $(\mathrm{Ku}$ et al., 2008; Lee, 2017; Pillay et al., 2015). Yet, in the case of ISCSs, mentoring provided by a school counselor at the pre-field experience and as part of field experience, has the potential to foster the development of a well-rounded professional who may or may not remain in the US to work.

The case of Nihan is demonstrative of the potential implications mentoring, as part of the DM-R, can have on ISCSs' academic, person/social, and professional development. Academically, we see the DM-R model implemented to reinforce Nihan's learning. The more experienced school counselor (the mentor/supervisor) 
used her understanding of Nihan's sociocultural background, as well as Nihan's personal and professional goals to facilitate growth. Through these interactions with various stakeholders in the school system, Nihan had the opportunity to nurture her social and networking repertoire. Although in Nihan's case, there were clear intentions of returning to her home country, there is evidence that in some cases, ICSs do remain in the US as professionals (Karaman, Schmit, Ulus, \& Oliver, 2018). Therefore, it is incumbent on faculty and site supervisors to provide sufficient support for personal adjustment and development of relevant skills in ISCSs. Whether they remain in the US or return to their home countries, ISCS competency, self-efficacy, and productivity, will be critical to the services they provide to their stakeholders.

Host universities, local communities, peer support, and faculty are critical elements to the adjustment and success of international students (Leong, 2015; Ramsay, Jones, \& Barker, 2007). However, data on international versus domestic counselor educators and supervisors is scarce in the literature. It can be argued that most international students in school counseling programs will learn from and interact with domestic rather than international educators and supervisors. Meeting the needs of ISCSs promotes multicultural education for both the mentors and the mentees. In addition, when an international student's learning is promoted: (a) it increases access to mental health for immigrants and international students in the host country; (b) competently trained professionals can return to their home countries and facilitate mental health to their citizens; and (c) ISCSs can make incredible contributions to existing or nonexisting counseling programs in their home countries $(\mathrm{Ng}, 2006)$. Specific to school counseling in the American school systems, the presence of ISCSs is likely to help raise multicultural awareness in all stakeholders within the designated schools.

Aside from the implications stated above, having international students can result in the economic well-being and increased internationalization in American universities (Hegarty, 2014). The American Council on Education (2012) reported that $93 \%$ of doctoral, $84 \%$ of master's, and $78 \%$ of baccalaureate universities have increased their population in internationalization on their campuses in the past few years. These percentages are likely to increase when international students experience goodwill and share positive experiences with other potential students from their home countries. Specifically, when ISCSs return to their home countries, they can speak positively about the American school counselor education programs, and convince potential ISCS to pursue similar career path.

Evidently, the idea of providing support to international students enrolled in school counseling programs is directly related to program leadership in culture as it addresses specific cultural needs of a population in school counseling programs. As the counseling profession is constantly evolving, program coordinators, faculty members, and community school counselors can take the initiative to provide support for ISCSs by paying attention to diversity and multicultural needs. Mentoring and the use of the DM-R serve as an appropriate model to promote effective teaching, make practice relevant, and foster success for ISCSs. This model also seems to ensure that the ISCSs' adjustment needs are factored into the curriculum as part of a developmentally appropriate practice. 


\section{REFERENCES}

Akkurt, M. N., Ng, K., \& Kolbert, J. (2018). Multicultural discussion as a moderator of counseling supervision-related constructs. International Journal of the Advancement of Counseling, 40(4), 455-468. https://doi.org/10.1007/s10447018-9337-z

American Council on Education. (2012). Mapping internationalization on U.S. campuses. Retrieved from http://www.acenet.edu

American School Counselor Association. (2012). National model: A framework for school counseling programs. Alexandria, VA: Author.

American School Counselor Association. (2016). ASCA ethical standards for school counselors.

Retrieved

from https://www.schoolcounselor.org/asca/media/asca/Ethics/EthicalStandards2016 .pdf

Anderson, E. M., \& Shannon, A. L. (1988). Toward a conceptualization of mentoring. Journal of Teacher Education, 39, 38-42. https://doi.org/10.1177/002248718803900109

Behl, M., Laux, J. M., Roseman, C. P., Tiamiyu, M., \& Spann, S. (2017). Needs and acculturative stress of international students in CACREP programs. Counselor Education and Supervision, 56(4), 305-318. https://doi.org/10.1002/ceas.12087

Bernard, J. M. (1979). Supervisor training: A discrimination model. Counselor Education and Supervision, 19(1), 60-68. https://doi.org/10.1002/j.15566978.1979.tb00906.x

Bernard, J. M., \& Goodyear, R. K. (1998). Fundamentals of clinical supervision. Boston, MA: Allyn and Bacon.

Bernard, J. M., \& Goodyear, R. K. (2014). Fundamentals of clinical supervision. Upper Saddle River, NJ: Pearson Education

Boafo-Arthur, S. (2014). Acculturative experiences of Black-African international students. International Journal of Advanced Counseling, 36(2), 115-124. https://doi.org/10.1007/s10447-013-9194-8

Borders, D. L. (2014). Best practices in clinical supervision: Another step in delineating effective supervision practice. American Journal of Psychotherapy, 68(2), 151-162. https://doi.org/10.1176/appi.psychotherapy.2014.68.2.151

Borders, D. L., Brown, J. B., \& Purgason, L. L. (2015). Triadic supervision with practicum and internship counseling students: A peer supervision approach. The Clinical Supervisor, $34(2)$,

232-248. https://doi.org/10.1080/07325223.2015.1027024

Burlew, L. D., \& Alleyne, V. L. (2010). A pedagogical paradigm for international graduate students studying community counseling. The Journal for Counselor Preparation and Supervision, 2(1), 23-36. http://repository.wcsu.edu/jcps/vol2/iss $1 / 4$

Council for Accreditation of Counseling and Related Educational Programs. (2015). 2016 CACREP Standards. Retrieved from http://www.cacrep.org/forprograms/2016-cacrep-standards/

Council for Accreditation of Counseling and Related Educational Programs. (2016). CACREP vital statistics 2015: Results from a national survey of accredited 
programs. Alexandria, VA: Author. Retrieved from https://issuu.com/cacrep/docs/2015_cacrep_vital_statistics_report

Education USA. (2018). What are English language programs? Retrieved from https://educationusa.state.gov/your-5-steps-us-study/research-youroptions/english-language/what-are-english-language-programs

Gautz, C. (2017). Rise in international students boosts universities' bottom line, diversity. $\quad$ Retrieved from http://www.crainsdetroit.com/article/20140803/NEWS/308039999/riseininternational-students-boosts-universities-bottom-line

Hanassab, S., \& Tidwell, R. (2002). International students in higher education: Identification of needs and implications for policy and practice. Journal of Studies in International Education, 6, 305-322. https://doi.org/10.1177/102831502237638

Hegarty, N. (2014). Where are we now-The presence and importance of international students to universities in the United States. Journal of International Students, 4(3), 223-235.

Hirai, R., Frazier, P., \& Syed, M. (2015). Psychological and sociocultural adjustment of first year international students: Trajectories and predictors. Journal of Counseling Psychology, 62(3), 438-452. https://doi.org/10.1037/cou0000085

Institute of International Education. (2018). Open doors data: Enrollment trends. Retrieved from https://www.iie.org/en/Research-and-Insights/OpenDoors/Data/International-Students/Enrollment

John-Steiner, V., \& Mahn H. (1996). Sociocultural approaches to learning and development: A Vygotskian framework. Educational Psychologist, 31, 191-206. https://doi.org/10.1080/00461520.1996.9653266 \}

Karaman, M. A., Schmit, M. K., Ulus, I. C., \& Oliver, M. (2018). International counseling students' perception of ethics. Journal of International Students, 8(2), 677-695. http://jistudents.org/doi: 10.5281/zenodo.1250370

Ku, H.-Y., Lahman, M. K. E., Yeh, H.-T., \& Cheng, Y. -C. (2008). Into the academy: Preparing and mentoring international doctoral students. Educational Technology Research and Development, 56(3), 365-377. http://dx.doi.org/10.1007/s11423-007-9083-0

Lee, S. (2017). Peer support for international doctoral students in managing supervision relationships. Journal of International Students, 7(4), 1096-1103. https://doi.org/ 10.5281/zenodo.1035971

Leong, P. (2015). Coming to America: Assessing the patterns of acculturation, friendship formation, and the academic experiences of international students at a U.S. college. Journal of International Students, 5(4), 459-474.

Lunenberg, F.C. (2010). Schools as open systems. Schooling, 1(1), 1-5. Retrieved from

http://www.nationalforum.com/Electronic\%20Journal\%20Volumes/Lununburg, $\% 20$ Fred $\% 20$ C. $\% 20$ Schools $\% 20$ as $\% 20$ Open $\% 20$ Systems $\% 20$ Schooling $\% 20 \mathrm{~V}$ $1 \% 20 \mathrm{~N} 1 \% 202010 . \mathrm{pdf}$

Meany-Walen, K., Davis-Gage, D., \& Lindo, N. (2016). The impact of wellnessfocused supervision on mental health counseling practicum students. Journal of Counseling \& Development, 94(4), 464-472. https://doi.org/10.1002/jcad.12105 
McDowell, T., Fang, S., Kosutic, I., \& Griggs, J. (2012). Centering the voices of international students in family studies and family therapy graduate programs. Journal of Marital and Family Therapy, 38(1), 332-347. https://doi.org/10.1111/j.1752-0606.2012.00310.x

Mellen, A., \& Murdoch-Eaton, D. (2015). Supervisor or mentor: Is there a difference? Implications for paediatric practice. Archives of Disease in Childhood, 100(9), 1-6. https://doi.org/10.1136/archdischild-2014-306834

Mittal, M., \& Wieling, E. (2006). Training experiences of international doctoral students in marriage and family therapy. Journal of Marital and Family Therapy, 32(3), 369-383. https://doi.org/10.1111/j.1752-0606.2006.tb01613.x

$\mathrm{Ng}, \mathrm{K}$. (2006). International students in CACREP-accredited counseling programs. Journal of Professional Counseling: Practice, Theory, and Research, 34(1 \& 2), 20-32.

Ng, K., \& Smith, S. D. (2009). Perception and experiences of international trainees in counseling and related programs. International Journal for the Advancement of Counselling, 31(1), 57-70. https://doi.org/10.1007/s10447-008-9068-7

$\mathrm{Ng}$, K., \& Smith, S. D. (2012). Training level, acculturation, role ambiguity, and multicultural discussions in training and supervising international counseling students in the United States. International Journal for the Advancement of Counselling, 34(1), 72-86. https://doi.org/10.1007/s10447-011-9130-8

Nilsson, J. E. (2007). International students in supervision: Course self-efficacy, stress, and cultural discussions in supervision. The Counselor Supervisor, 26(1 \& 2), 35-47. https://doi.org/10.1300/J001v26n01_04

Norlin, J. M. (2009). Human behavior and the social environment: Social systems theory. Upper Saddle River, NJ: Allyn \& Bacon.

Olivas, M., \& Li, C. (2006). Understanding stressors of international students in higher education: What college counselors and personnel need to know. Journal of Instructional Psychology, 33(3), 217-222.

Park, S., Lee, H. J., \& Wood, S. M. (2017). Experiences of international students in practicum and internship courses: A consensus qualitative research. Journal of Counselor Preparation and Supervision, 9(2), 96-121. http://dx.doi.org/10.7729/92.1137

Peer, K., \& McClendon, R. C. (2002). Sociocultural learning theory in practice: Implications for athletic training educators. Journal of Athletic Training, 37(4), $136-140$.

Pillay, Y., Fulton, B., \& Robertson, T. (2015). A conceptual framework for incorporating mentoring in supervision of mental health professionals. In A. A. Howley \& M. B. Trube (Eds.), Mentoring for the professions: Orienting toward the future (pp. 353-362). Charlotte, NC; Information Age.

Ramsay, S., Jones, E., \& Barker, M. (2007). Relationship between adjustment and support types: Young and mature-aged local and international first year university students. Higher Education, 54(2), 247-265. http://dx.doi.org/10.1007/s10734-006-9001-0

Reese, S. (2006). The art of mentoring. Technique, 81(6), 14-19. 
Schulte, S., \& Choudaha, R. (2014). Improving the experiences of international students. Change: The Magazine of Higher Learning, 46(6), 52-58. https://doi.org/10.1080/00091383.2014.969184

Tidwell, R., \& Hanassab, S. (2007). New challenges for professional counsellors: The higher education international student population. Counseling Psychology Quarterly, 20(4), 313-324. https://doi.org/10.1080/09515070701573927

United States Citizenship and Immigration Services. (2018). Students and employment. Retrieved from https://www.uscis.gov/working-unitedstates/students-and-exchange-visitors/students-and-employment

Vygotsky, L.S. (1978). Mind in society: The development of higher psychological processes. Cambridge, MA: Harvard University Press

Yip, M. (2014). A win-win for international student mentor programming. Journal of College Admission, 224, 2-3. Retrieved from http://connection.ebscohost.com/c/articles/97394378/win-win-internationalstudent-mentor-programming

Zhu, Y., \& Degeneffe, C. E. (2011). International students in rehabilitation counseling education programs: Results from a national survey. Rehabilitation Education, 25(1 \& 2), 73-86.

BRIDGET ASEMPAPA, PhD, is an Assistant Professor of Counselor Education at West Chester University of Pennsylvania, in West Chester, Pennsylvania. Her research interests include supervision models in school counseling, adjustment challenges among international students in counselor education programs, integrated care, and ethical issues in counseling. Email: basempapa@wcupa.edu 